\title{
Criminological innovations in criminality prevention: status and perspectives
}

\author{
Anna Valeryevna Serebrennikova ${ }^{1^{*}}$ and Maria Sergeyevna Serebrennikova ${ }^{2}$ \\ ${ }^{1}$ Lomonosov Moscow State University, Faculty of Law, Department of Criminal Law and \\ Criminology, Moscow, Russia \\ ${ }^{2}$ Lomonosov Moscow State University, Faculty of Law, Moscow, Russia
}

\begin{abstract}
A growing number of new types of criminality causes concern of the society, authorities and, in particular, of criminologists, since the penetration of criminals into the virtual environment and learning to use new technologies become dangerous and adjust criminal motivation. The sophistication of criminality prevention and countering defines the goal of this research consisting in a thorough scientific understanding of existing criminological methods. Modern informational-analytical area of activity of law-enforcement authorities includes the use of digital criminological tools under criminality prevention programs, mathematical methods of its analysis, making up profiles, etc. They are usually applied for criminological analysis and prediction but it has no theoretical basis that addresses the issues of countering digital crimes and that is being formed currently based on criminological neo-classics and achievements of social and human sciences and digital criminology. As a methodological basis for the research, a general scientific dialectic method of scientific cognition was used. Moreover, the paper uses a number of particular scientific methods that include historical-legal, comparative-legal methods, statistic observation and analysis of generalized information. The novelty of the research consists in the fact that its results can be used by experts whose professional activity is intended against crimes.
\end{abstract}

Keywords: innovations, criminology, crime prevention, informational society, technologies

\section{Introduction}

Modern criminality indicators prevent from formulating a comprehensive understanding of its dynamics and trends and are only a tool to evaluate the work of the system of lawenforcement authorities. This problem is not new for researchers in the area of criminology that frequently state limitations of tools available to practical workers whose activity is intended against crimes [1].

During the last two decades, many researchers studied innovations as a subject of criminological science and its important tool. Most relevant include the studies of $[2,3]$. The concepts of social technologies and engineering were quite thoroughly studied in theoretical

\footnotetext{
* Corresponding author: serebranna@hotmail.com
} 
criminology [4]. Moreover, these categories were classified, a methodological basis was developed and perspective trends were defined for the development of a new vector of scientific search in criminology [5].

Innovations for science in general and for criminology, in particular, are a dynamically developing trend in theoretical understanding and its subject and coordinates of these systems are variable. Nevertheless, it should be noted that innovative processes and technologies develop separately from theoretical studies and may lose their relevance at the time when they are actually implemented into anti-criminal practice.

The goal of this study is the generalization of innovations that will improve the efficiency of crime prevention when used in theoretical and practical criminology.

\section{Methods}

As a methodological basis for the research, a general scientific dialectic method of scientific cognition was used. Moreover, the paper uses a number of particular scientific methods that include historical-legal, comparative-legal methods, statistic observation and analysis of generalized information.

\section{Results}

The analysis of modern theory and practice of crime prevention proves that the development of technologies (even advanced) has no significant effect on the methodological basis of studies in the field of criminology. Improvement of the conceptual basics of criminology in terms of the use of innovations is usually very slow, which prevents from defining potential trends of improvement for the crime prevention theory taking into account its current condition and social processes occurring today and predicted in the future. Pure technologies do not disclose how Russian criminology will form in qualitative terms and how it will be able to respond to global challenges. The relevance of the futurological aspect should be noted, which is treated as a component of the criminological theory [6].

Development of prediction opportunities for crime development trends must also be taken into account. These issues are given in the literature of recent years as an individual area in the criminality theory [7].

As for the development of systemic links between criminology and other legal and social sciences, no organic unity has been reached between the general theory of criminality and other areas of knowledge applicable to criminality analysis, which Antonyan deems to be the main reason of extremely slow development of the Russian criminology [8].

This systemic approach can support the formation of digital criminology as a relatively individual branch of criminological science and practice.

Focusing on cross-disciplinary integration of scientists representing a number of sciences of the so-called criminological cycle is relevant [9, p. 20]. The literature also shows the need to return criminology to a holistic conventional world view that will be quickly filled with new knowledge and even their branches (in accordance with the development of informational society). A special role will be played by new digital criminology that will converge legal, humanitarian and natural scientific knowledge.

Criminological literature for issues of criminal personality development almost takes no account of the specifics of digital society development. A mechanistic, conventional and somewhat simplified view upon a criminal personality dominates in Russian criminology, which is usually depersonalized. Sentences claiming that human nature suggests disposition to crimes become a common feature of criminalistic literature. This position actually repeats (develops) Christian ideas of human nature depravity. This results in a dubious conclusion 
that everyone has the potential of committing a crime, and committing mainly depends on coincidence [10].

The digital world gave rise to new variability of situation development, since the above circumstances can occur in real and virtual worlds. Crimes committed under the influence of computer (network) games [11], communication in social networks, various forms of Internet fraud require criminological analysis [12]. In this sense, it seems relevant to focus again on the criminal personality in criminological studies [13].

Predictions of the so-called fourth industrial revolution [14] suggest a rapid development of technologies, systemic transformation of production and management, which will result in the global growth of life quality, on the one hand, and growth of financial and social inequality, on the other hand, along with labor market imbalance [15]. These aspects must be taken into account by criminologists to build a model of nearest future social development. Social consequences of predicted new industrial revolutions will inevitably become general determinants of the criminality of the future since it has always been in the past [16]. In this manner, development perspectives of digital criminology must be mainly based on existing development predictions of Russian criminality.

Digital aspects in the modern criminological doctrine are viewed from technological positions. The authors tried to avoid classical canons and pay much attention to digital carriers of information that today contain criminologically (and criminalistically) important digital traces and specimens reflecting individual traits and behavior specifics (criminal methods) of individuals irrespective of their will [17].

The range of subjects of the criminal investigation in the modern situation is supplemented by qualitatively new means of cognition of illegal activities including that in the digital environment. These are methods of monitoring and screening of large volumes of data (files) (big data) and traceable cause-and-effect relationships with suspects - users of digital devices.

One of the most relevant issues in using Big Data technology is the correct selection and ensuring validity of materials to provide a form understood by the computer algorithm and fast access to the desired information from large arrays of data [1]. Another issue deserving attention is a question of perception of innovative technologies and statistical methods of data processing by researchers in the field of criminology as well as the integration of these technologies into the common practice of law enforcers [18].

One of the new tools in criminality cognition is the digital profiling of criminal behavior achieved using mathematical modeling and prediction. These methods allowed for structurization and modeling of the digital profile (portrait) of a criminal. Today's digital profiling has significantly expanded opportunities, for example, associating a specific digital device with a specific user.

In modern Northern-American studies, profiling of crimes in investigations of various categories of criminal cases is deemed to be an evolutionary trend, but it is still in its infancy in terms of interrelation. Each year new forms of criminality appear, and efficiency of cybercriminal profiling has become an important topic for discussion. Thanks to the analysis of specific cases and study of potential problems, profiling of crimes has been supported as a relevant tool in the investigation of cybercrimes. Using innovative technologies in crime prevention is quite a common practice in the USA. The USA National Security Agency uses criminal activity profiling technologies in the prevention of terroristic attacks and other types of organized criminal activity (Prism) [19].

The European Union now develops a regulatory framework for member states to obtain information from business representatives concerning their clients if they undertake or plan criminal activity [20]. 


\section{Discussion}

The analysis and generalization of views in criminology studies and the existing practice of criminality countering shows that despite perspectives of using innovations in anti-criminal practice such innovations are not always timely used by law enforcers due to a number of objective reasons. This research does not claim to achieve completeness (due to limited space), and we have highlighted only general modern trends and areas whose development can improve efficiency. Except for the above issues, we should note that there is no agreement and unity in empirical studies in criminology that provide a basis to prevent crimes. Existing technological solutions will quickly lose their relevance and efficiency even in case of slight social changes.

\section{Conclusion}

As a conclusion, we shall agree that new criminality evolves, which has specific attributes of the informational era that will aggravate and grow in the nearest future. Efficiency prediction of countering such criminality is pessimistic in general, and authors predict reduced efficiency of countering. It should be concluded that actively developing technologies have created efficient tools to search and generalize information significant to prevent criminal activity and its sufficient use is just a question of time.

\section{References}

1. S.V. Ivantsov, E.L. Sidorenko, B.A. Spasennikov, Yu.M. Berezkin, Ya.A. Sukhodolov, Russian Journal of Criminology, 13, 85-93 (2019). https://doi.org/10.17150/25004255.2019.13(1).85-93

2. S.A. Butkevich, Criminal Law and Criminology 2(81) (2017). Accessed on: December 04, 2020. [Online]. Available: http://cyberleninka.ru/article/n/suschnost-innovatsiy-iih-vliyanie-na-razvitie-obschestvennyh-protsessov-sotsialno-pravovaya-ikriminologicheskaya-otsenki

3. A.V. Serebrennikova, Russian Journal of Criminology, 14, 423-430 (2020). https://doi.org/10.17150/2500-4255.2020.14(3).423-430

4. A.V. Simonenko, E.V. Gribanov, Society and Law, 1(55) 121-128 (2016). Accessed on: April 12, 2021. [Online]. Available: http://libkrumvd.ru/museum/files/oip/sl-20161(55).pdf

5. V.I. Chervonyuk, Vestnik of the Moscow University of the Ministry of Internal Affairs of Russia, 5, 189-194 (2010)

6. A.N. Ignatov, Society and Law, 4(58), 94-99 (2016)

7. I.M. Kleymenov, Vestnik OmGU. Seriya Pravo, 4(53), 134-143 (2017). https://doi.org/10.25513/1990-5173.2017.4.134-143

8. Y.M. Antonyan, Legal Science and Law-Enforcement Practice, 4(30), 67-76 (2014)

9. G.N. Gorshenkov, Criminology as Expanded Science on Criminality: Period of Development (Nizhnii Novgorod Law Academy, Nizhnii Novgorod, 2015)

10. V.A. Nomokonov, Vozvrashchenie lichnostnogo podkhoda neobkhodimo [The return of the personal approach is necessary], in the collection of articles, The identity of the criminal and its criminological research (Russian Criminological Association, Moscow, 2018) 
11. A.N. Shokhin, Journal of Nizhny Novgorod Academy of the Ministry of Internal Affairs of Russia, 1(1), 136-139 (2014)

12. E.V. Tischenko, Bulletin of Higher Education Institutes. Northern-Caucasus Region. Social Sciences, 6(184), 126-132 (2014)

13. K.D. Titayev, D.A. Skugarevsky, A.V. Knorre, Vestnik of Saint Petersburg University. Law, 9, 91-101 (2018). https://doi.org/10.21638/11701/spbu14.2018.107

14. A.B. Syritsky, K.G. Potapov, M.I. Kiselev, A.S. Komshin, Standards and Quality, 6, 64-68 (2018)

15. Min Xu, Jeanne M. David, Suk Hi Kim, International Journal of Financial Research, 9(2) (2018). https://doi.org/10.5430/ijfr.v9n2p90

16. D.D. Shmygin, Problemnye voprosy kriminologicheskogo planirovaniya i prognozirovaniya organov vnutrennikh del [Problematic issues of criminological planning and forecasting of internal affairs bodies], in Collection of Articles of the International Scientific-Practical Conference, Concept of Development and Efficient Use of Scientific Potential of Society, in two parts, part 2 230-235 (Kaluga, 2020)

17. P. Reedy, Forensic Science International: Synergy, 2, 489-520 (2020). https://doi.org/10.1016/j.fsisyn.2020.01.015

18. K.B. Anderson, E. Durbin, M.A. Salinger, Journal of Economic Perspectives, 22(2), 171-192 (2008). https://doi.org/10.1257/jep.22.2.171

19. NSA Prism program taps in to user data of Apple, Google and others. Accessed on: April 12, 2021. [Online]. Available: https://www.theguardian.com/world/2013/jun/06/us-tech-giants-nsa-data

20. Regulation (EU) 2016/679 of the European Parliament and of the Council of 27 April 2016 on the protection of natural persons with regard to the processing of personal data and on the free movement of such data, and repealing Directive 95/46/EC (General Data Protection Regulation). Accessed on: April 12, 2021. [Online]. Available: https://eur-lex.europa.eu/legalcontent/EN/TXT/?qid=1552662547490\&uri=CELEX\%3A32016R0679 